\title{
Unreasonable Suspicion: Relying on Refusals to Support Terry Stops
}

\author{
Rachel Karen Laser $\dagger$
}

The Supreme Court has repeatedly held that a person's refusal to consent to a police request during a noncoercive police encounter ${ }^{1}$ cannot, by itself, provide the basis for a stop or search-including a "Terry stop" or "Terry search." The Court has not decided, however, whether a refusal to consent to a police request can constitute a part of the basis for a Terry stop. The circuit courts addressing the question have reached different conclusions, sometimes with little or no analysis. ${ }^{3}$

This question is important to the preservation of (ever-diminishing) Fourth Amendment rights for three main reasons. First, a court that permits the use of a refusal as part of the basis for a Terry stop is less likely to hold that a particular stop or search violates the Fourth Amendment. Thus, a court's decision to permit the use of the refusal ultimately determines whether, if the Terry search revealed incriminating evidence, the evidence will be admitted. ${ }^{4}$ Second, police often confront and search peo-

† B.A. 1991, Harvard University, J.D. 1995, The University of Chicago.

1 A noncoercive or "consensual" encounter is an encounter where a person is "free to decline the officers' requests or otherwise terminate the encounter." Florida $v$ Bostick, 501 US 429, 436 (1991). Thus, if a person is not free to decline the officers' requests, then the police encounter is considered a "seizure" within the meaning of the Fourth Amendment and is scrutinized under the Fourth Amendment reasonableness standard. Id at 435 .

2 Terry stops or searches are coercive police stops and searches that are not as extensive in intrusiveness or duration as full-blown stops and searches-or arrests. See Terry $v$ Ohio, 392 US 1, 26 (1968) (permitting a "brief... intrusion upon the sanctity of the person," where the officers had reasonable and articulable suspicion of criminal activity). This Comment will use "Terry stop" and "Terry search" interchangeably. In Terry, the Supreme Court, using "seizure" interchangeably with "search," underscored that where a brief stop-or "Terry stop" - was reasonable under the Fourth Amendment, so too was a protective search-or "Terry search." Id at 30.

${ }^{3}$ Compare United States v Sterling, 909 F2d 1078, 1083 (7th Cir 1990); United States $v$ Withers, 972 F2d 837, 843 (7th Cir 1992) (permitting an officer to use a person's refusal to consent to a search request as support for a Terry stop), with United States $v$ White, 890 F2d 1413, 1417 n 4 (8th Cir 1989); United States $v$ Wilson, 953 F2d 116, 126 (4th Cir 1991); United States $v$ Carter, 985 F2d 1095, 1097 (DC Cir 1993) (prohibiting an officer from using a person's withdrawal of consent to a search request as support for a Terry stop).

4 Under the "exclusionary rule," evidence of criminal guilt obtained through unrea- 
ple who do not possess anything illegal, causing them inconvenience and intruding on their privacy. ${ }^{5}$ If a request for consent can generate a factor that can be used as support for a Terry stop, police will approach individuals without any basis more often. The result-increased police discretion to Terry stop-undermines the goal of the Fourth Amendment to check police discretion. Finally, the people likely to be most affected if a refusal to consent is considered are African Americans and other minorities, whom police disproportionately confront without sufficient basis. ${ }^{6}$ Almost all modern cases addressing the use of refusal to consent as support for a Terry stop occur as a result of the war on drugs. ${ }^{7}$ Since those arrested for drug law violations are disproportionately African American, ${ }^{8}$ the context of the

sonable searches is inadmissible at trial. See Wong Sun $v$ United States, 371 US 471,485 (1963) ("The exclusionary rule has traditionally barred from trial physical, tangible materials obtained either during or as a direct result of an unlawful invasion.").

5 Professor Paul Finkelman has argued that many people who are Terry stopped do not possess anything illegal:

At the bus station in Buffalo, New York, for example, DEA agents admitted to stopping 80 passengers a month who fit their [drug courier] profile. The agents also testified that these 80 warrantless searches led to three or four arrests per month. In other words, because of these profile searches more than 900 people per year were delayed in their travels even though they had committed no offense and done nothing wrong. They simply looked suspicious.

Paul Finkelman, The Second Casualty of War: Civil Liberties and the War on Drugs, $66 \mathrm{~S}$ Cal L Rev 1389, 1418 (1993) (citations omitted). See also United States v Sokolow, 490 US 1, 11 (1989) (Marshall dissenting) ("Because the strongest advocates of Fourth Amendment rights are frequently criminals, it is easy to forget that our interpretations of such rights apply to the innocent and the guilty alike."). These "innocent" people generally will not challenge the search, because, with no incriminating evidence to suppress, a lawsuit would not be worth the time and money. See Tracey Maclin, The Central Meaning of the Fourth Amendment, 35 Wm \& Mary L Rev 197, 244 (1993) ("Even though individual privacy has been invaded, individuals subjected to such searches are not likely to complain because it is probably not worth the bother.").

${ }^{6}$ See, for example, Bostick, 501 US at 441 n 1 (Marshall dissenting); Terry, 392 US at 14-15 (noting that "minority groups, particularly Negroes, frequently complain" about "wholesale harassment by certain elements of the police community").

7 See, for example, Withers, 972 F2d at 839 (DEA officers used defendant's refusal to consent to a search of her bag as reasonable suspicion to search for narcotics); White, 890 F2d at 1413 (defendant's refusal to allow DEA agents to search his luggage led to Terry stop); Carter, 985 F2d at 1096 (defendant's refusal to consent provided basis for dog sniff for narcotics); Wilson, 953 F2d at 116 (DEA officers used defendant's refusal to consent to search "bulge" in defendant's coat pocket which turned out to be crack cocaine).

${ }^{8}$ Out of the 690,855 drug abuse offenses, 381,914 offenders were White (55.3\%), 303,764 were Black (44.0\%), 2,076 were American Indian or Alaskan Native (0.3\%), and 3,101 were Asian or Pacific Islander (0.4\%). Bureau of Justice Statistics, Sourcebook of Criminal Justice Statistics-1991 448-49 table 4.11 (1992). In contrast, as of 1992 the percent distribution of the American resident population was $83.5 \%$ White, $12.4 \%$ Black, and 4.1\% Other. United States Bureau of the Census, Statistical Abstract of the United 
Terry stop question further ensures that racial minorities will be most affected.

This Comment argues that a refusal to consent cannot be used as part of the basis for a Terry stop. The same concerns militating against the use of a refusal to consent as the sole basis for a Terry stop also prohibit its use as part of the basis. If refusal supports a Terry stop, consensual searches are really involuntary, noncoercive police encounters are in fact seizures, and police discretion is broadened rather than checked-defeating the very purpose of the Fourth Amendment.

Part I of this Comment discusses Supreme Court decisions on Fourth Amendment issues that provide guidance to courts confronted with Terry stop and search cases. Part II describes the various approaches circuit courts have taken concerning whether to consider a refusal to consent as support for a Terry stop. In Part III, this Comment argues that permitting police officers to use an individual's refusal to consent to a police request during a noncoercive police encounter as part of the basis for a Terry stop and search denies an individual adequate Fourth Amendment protection.

\section{SUPREME COURT Fourth AMENDMENT JURISPRUDENCE}

First, to differentiate a Terry search from other types of searches, this Part discusses the three types of searches police may conduct: consensual searches, probable cause searches, and Terry searches. Next, it focuses on the Court's decisions determining when Terry stops and searches are reasonable and thus constitutional under the Fourth Amendment.

\section{A. Three Types of Searches}

The Fourth Amendment of the United States Constitution states:

The right of the people to be secure in their persons, houses, papers, and effects, against unreasonable searches and seizures, shall not be violated, and no Warrants shall issue, but upon probable cause, supported by Oath or affirmation, and

States: 1994 table 12 at 13 (114th ed 1994). Thus, while blacks compose only $12.4 \%$ of the total population, they compose $44 \%$ of those arrested for drug-law arrests. 
particularly describing the place to be searched, and the persons or things to be seized. ${ }^{9}$

The Fourth Amendment is in large part a check on police discretion. ${ }^{10}$ In Johnson $v$ United States, the Supreme Court stated that "[t]he point of the Fourth Amendment, which often is not grasped by zealous officers,"11 is to protect "one of the most fundamental distinctions between our form of government, where officers are under the law, and the police-state where they are the law."12 In United States $v$ Mendenhall, the Court explained: "The purpose of the Fourth Amendment is not to eliminate all contact between the police and the citizenry, but 'to, prevent arbitrary and oppressive interference by enforcement officials with the privacy and personal security of individuals." ${ }^{\prime 13}$ In order to enforce the Fourth Amendment, the Court crafted the exclusionary rule, under which evidence of criminal guilt obtained through illegal searches is inadmissible at trial. ${ }^{14}$

The Court has identified three types of police searches, each requiring a different level of scrutiny under the Fourth Amendment: consensual searches, which require no scrutiny; full-blown searches against a person's will, which require probable cause; and Terry or investigative searches against a person's will, which require reasonable, articulable suspicion.

9 US Const, Amend IV.

10 See, for example, Maclin, $35 \mathrm{Wm} \&$ Mary L Rev at 201, 213-14 (cited in note 5) ("The central meaning of the Fourth Amendment is distrust of police power and discretion.... [T] The Court must focus on the 'underlying vision' of the amendment, which 'places the magistrate as a buffer between the police and the citizenry, so as to prevent the police from acting as judges in their own cause." (citations omitted).

11333 US 10, 13 (1948).

12 Id at 17.

13446 US 544, 553-54 (1980), quoting United States v Martinez-Fuerte, 428 US 543, 554 (1976).

${ }_{14}$ See Wong Sun $v$ United States, 371 US 471, 485 (1963) ("The exclusionary rule has traditionally barred from trial physical, tangible materials obtained either during or as a direct result of an unlawful invasion."); Terry, 392 US at 12 ("Ever since its inception, the rule excluding evidence seized in violation of the Fourth Amendment has been recognized as a principal mode of discouraging lawless police conduct."). Professor Amar has criticized the exclusionary rule as being a sloppy way of deterring unreasonable police behavior. See Akhil Reed Amar, Fourth Amendment First Principles, 107 Harv L Rev 757, 799 (1994) ("The exclusionary rule renders the Fourth Amendment contemptible in the eyes of judges and citizens. Judges do not like excluding bloody knives, so they distort doctrine, claiming the Fourth Amendment was not really violated."). 


\section{Consensual searches.}

Generally, if an individual consents to a police officer's request to search, the search is considered "voluntary" and thus does not trigger Fourth Amendment scrutiny. ${ }^{15}$ The Supreme Court has held that "[w]hen a prosecutor seeks to rely upon consent to justify the lawfulness of a search, he has the burden of proving that the consent was, in fact, freely and voluntarily given." Consent, to be valid, "must be unequivocal, specific and intelligently given, uncontaminated by any duress or coercion. ${ }^{.17}$ The question of voluntariness of consent is a question of fact, ${ }^{18}$ and thus a court must affirm the lower court's finding of voluntary consent unless it is shown to be clearly erroneous. ${ }^{19}$ Subjective traits, including the suspect's age, education level, intelligence, the length of detention, and the nature of the questioning are all considered in a "totality of the circumstances" assessment of voluntariness. ${ }^{20}$ In addition, whether the suspect was advised of the right to refuse consent is "highly relevant" and may result in a determination that consent was not voluntary, although it does not preclude a finding of voluntariness. ${ }^{21}$

When a person has been unconstitutionally seized prior to giving consent, any consent given thereafter is generally considered tainted, and thus involuntary. ${ }^{22}$ If a court finds that a defendant was seized illegally, the court must next determine whether there is a causal connection between the illegal seizure and the consent. ${ }^{23}$ In Brown $v$ Illinois, the Supreme Court held

15 See Florida v Bostick, 501 US 429, 434 (1991).

${ }^{16}$ Bumper v North Carolina, 391 US 543, 548 (1968).

17 United States v McCaleb, 552 F2d 717, 721 (6th Cir 1977), citing Simmons $v$ Bomar, 349 F2d 365, 366 (6th Cir 1965).

${ }^{18}$ Schneckloth $v$ Bustamonte, 412 US 218, 227 (1973).

19 See McCaleb, 552 F2d at 720-21, citing United States $v$ Hearn, 496 F2d 236, 242 (6th Cir 1974).

${ }^{20}$ Schneckloth, 412 US at 226.

${ }^{21}$ Mendenhall, 446 US at 558-59, citing Schneckloth, 412 US at 234 ("Although the Constitution does not require 'proof of knowledge of a right to refuse as the sine qua non of an effective consent to a search,' such knowledge was highly relevant to the determination that there had been consent.").

${ }^{22}$ See Wong Sun $v$ United States, 371 US 471, 486-87 n 12 (1963). See also McCaleb, $552 \mathrm{~F} 2 \mathrm{~d}$ at 721 ("Factors tending to militate against a finding of voluntariness include an unconstitutional stop; an unconstitutional arrest."); United States $v$ Bazinet, 462 F2d 982, 989 (8th Cir 1972) (" $[$ TT]he mere fact that a person has been arrested in violation of his constitutional rights casts grave doubt upon the voluntariness of a subsequent consent. The government has a heavy burden of proof in establishing that the consent was the voluntary act of the arrestee and that it was not the fruit of the illegal arrest.").

23 See Dunaway $v$ New York, 442 US 200, 216-18 (1979). 
that in determining whether the consent is the result of the illegal seizure, courts should consider the following: the time elapsed between the illegal seizure and the subsequent consent; the existence of intervening circumstances; and "the purpose and flagrancy of the official misconduct." ${ }^{24}$ If the court finds the consent to be tainted by the illegal seizure, then the search is considered involuntary. ${ }^{25}$ If the consent is found to be sufficiently attenuated, the court applies the "totality of the circumstances" voluntariness test used for consensual searches generally. ${ }^{26}$

In Florida $v$ Bostick, ${ }^{27}$ the Supreme Court indicated that it has a very narrow vision of what constitutes an unconstitutional seizure. In Bostick, two officers, "complete with badges, insignia and one of them holding a recognizable zipper pouch, containing a pistol," boarded a bus bound from Miami to Atlanta during a stopover, eyed the passengers, and approached Bostick without articulable suspicion. ${ }^{28}$ The officers explained they were narcotics agents, requested permission to search Bostick's luggage, and explained that Bostick had the right to refuse to consent. ${ }^{29}$ Bostick consented to the search of his luggage, which contained cocaine. ${ }^{30}$ At trial, Bostick moved to suppress the cocaine found in his luggage claiming that it had been seized in violation of his Fourth Amendment rights. ${ }^{31}$

The Court concluded that a person is not seized during a police encounter if a "reasonable person would feel free to decline the officers' requests or otherwise terminate the encounter."32 The Court further explained that its "'reasonable person' test presupposes an innocent person, ${ }^{\text {"33 }}$ and that its seizure test "applies equally to police encounters that take place on trains, planes and city streets. ${ }^{n 4}$ The Bostick Court reversed the decision of the Florida Supreme Court and remanded the case. ${ }^{35}$

24422 US 590, 603-04 (1975). See also Dunaway, 442 US at 218.

25 See Dunaway, 442 US at 216-19. See also Note, Airport Drug Searches: Giving Content to the Concept of Free and Voluntary Consent, 77 Va L Rev 183, 200 (1991) ("If a consent has been tainted by an illegal seizure, it is necessarily involuntary.").

26 See text accompanying notes 17-21.

27501 US 429 (1991).

28 Id at 431.

29 Id at 431-32.

30 Id.

31 Id at 432 .

32 Id at 436 .

33 Id at 438 .

34 Id.

${ }^{35}$ Id at 440 . On remand, the court held that Bostick's consent to the search of his luggage was voluntary. See Bostick v Florida, 593 S2d 494, 495 (Fla 1992). 
In order to give credibility to its seizure test, the Bostick Court explained that an individual could feel free to decline an officer's requests or otherwise terminate the encounter because the Supreme Court had already established that a person's refusal to cooperate with police officers, by itself, could not constitute the basis for a seizure. The Bostick Court wrote:

[A]n individual may decline an officer's request without fearing prosecution. We have consistently held that refusal to cooperate, without more, does not furnish the minimal level of objective justification needed for a detention or seizure. ${ }^{36}$

The Court did not address whether a refusal could constitute a part of the basis for a seizure.

2. Searches against a person's will.

Unlike consent cases, extensive searches of individuals against their will always trigger Fourth Amendment scrutiny. By its very language, the Fourth Amendment demands that police obtain probable cause to conduct any unreasonable search or seizure. ${ }^{37}$ The Court has defined probable cause as "a fair probability that contraband or evidence of a crime will be found."38 The general rule is that police officers must obtain a warrant from a magistrate, based on their showing of probable cause, in order to search an individual or the individual's personal belongings, unless exigent circumstances make it impractical to obtain a warrant. ${ }^{39}$ The exigent circumstances exception permits warrantless searches when any delay would create a risk of physical harm or imminent destruction of evidence in the case of a serious crime. ${ }^{40}$

${ }^{36}$ Bostick, 501 US at 437 (emphasis added), citing Brief for the United States as Amicus Curiae Supporting Petitioner at 25, Bostick, 501 US 429. See also Florida $v$ Royer, 460 US 491, 498 (1983); Brown $v$ Texas, 443 US 47, $52-53$ (1979) (a defendant may not be punished solely for refusing to identify himself).

37 Chambers $v$ Maroney, 399 US 42, 51 (1970).

${ }^{38}$ Illinois $v$ Gates, 462 US 213, 238 (1983).

39 See Russell W. Galloway, Jr., Basic Fourth Amendment Analysis, 32 Santa Clara L Rev 737, 739, 748-73 (1992).

${ }^{10}$ See Comment, United States v. MacDonald: The Exigent Circumstances Exception and the Erosion of the Fourth Amendment, 20 Hofstra L Rev 407, 409 (1991). Some commentators argue that the exigent circumstances exception has been liberally and even unconstitutionally applied, particularly in narcotics cases. Id. See also Jacqueline J. Warner, The Exigent Circumstance Exception to the Warrant Requirement of the Fourth Amendment: What Criteria Must be Met?, 33 Howard L J 425, 435 (1991) (suggesting that 
3. Investigative searches.

In Terry $v$ Ohio, ${ }^{41}$ the Court carved out an exception to the probable cause requirement for nonconsensual searches. Under Terry, police can stop and frisk individuals without probable cause, provided that the investigating officer has reasonable and articulable suspicion that "criminal activity may be afoot and that the persons with whom he is dealing may be armed and dangerous. ${ }^{\prime 42}$ In Terry, the Court held that this exception covered only brief detentions, and the frisk-a practice now commonly referred to as a Terry search-was strictly "limited to that which is necessary for the discovery of weapons which might be used to harm the officer or others nearby." ${ }^{\prime 3}$ The Court explained that such behavior was permissible where the "specific and articulable facts which, taken together with rational inferences from those facts, reasonably warrant that intrusion. ${ }^{344}$

In deciding whether to allow a protective search, the Terry Court weighed the government's interest in conducting such searches against the invasion of constitutionally protected interests caused by such searches. The Court concluded that society's general interest in "effective crime prevention and detection" and the more immediate interest in police officer safety ${ }^{46}$ justified a slight intrusion "upon the sanctity of the person."

the scope of the exigent circumstances exception should be limited in order to preserve Fourth Amendment rights).

41392 US 1 (1968). In Terry, the Court upheld a protective and investigative stop conducted by a plainclothes officer who spotted two men repeatedly pacing, peering into a store window, and conferring. Id at 28-31.

42 Id at 30. For a criticism of the Terry search exception, see Minnesota $v$ Dickerson, 113 S Ct 2130, 2140 (1993) (Scalia concurring) (Terry searches should not be permissible because, at the time the Fourth Amendment was adopted, citizens were not searched with less than probable cause).

43 Terry, 392 US at 26. See also Dickerson, $113 \mathrm{~S} \mathrm{Ct}$ at 2136, citing Sibron $v$ New York, 392 US 40, 65-66 (1968) ("If the protective search goes beyond what is necessary to determine if the suspect is armed, it is no longer valid under Terry and its fruits will be suppressed.").

14 Terry. 392 US at 21 . The Court concluded that where the officer drew "specific reasonable inferences ... from the facts in light of his experience," a reasonable search for weapons may be justified. Id at 27 .

${ }^{45}$ Id at 22.

46 Id at 23.

47 Id at 26. Justice Harlan, in his concurrence, summarized the Court's rationale: where is no reason why an officer, rightfully but forcibly confronting a person suspected of a serious crime, should have to ask one question and take the risk that the answer might be a bullet." Id at 33 (Harlan concurring). 


\section{B. The Progeny of Terry}

Since Terry, the Supreme Court has struggled to determine when a police officer has the reasonable and articulable suspicion that a Terry stop and search requires. As the Court articulated in United States $v$ Cortez, the Terry standard is not self-evident in practice: 'Terms like 'articulable reasons' and 'founded suspicion' are not self-defining; they fall short of providing clear guidance dispositive of the myriad factual situations that arise. ${ }^{n 48}$

In Cortez, the Court applied the reasonable suspicion test to determine whether police officers had conducted a constitutional Terry stop and search of a vehicle suspected of transporting illegal aliens. ${ }^{49}$ The Court explained that, in order to determine whether there is reasonable suspicion, the officers must rely on their own expertise in assessing the combined importance of all objective facts they found significant. ${ }^{50}$ The Cortez Court thus licensed the lower courts to defer to police discretion.

Since Cortez, courts have interpreted the "totality of the circumstances" broadly, thus expanding the scope of what constitutes an acceptable Terry stop. In the drug-trafficking context, for example, the Court has held that police officers can conduct Terry stops even when the "totality of the circumstances" is nothing more than a set of innocent behaviors. In United States $v$ Sokolow, the Court found articulable, reasonable suspicion for a Terry stop where the respondent flew from Hawaii, spent only forty-eight hours in Miami, paid for two plane tickets with $\$ 2,100$ from a roll of $\$ 20$ bills containing nearly twice that much, and never checked his luggage, and where the agents had reasonable ground to believe that he was traveling under an alias. ${ }^{51}$ Affirming the DEA agents' interpretation of the facts, the Court acknowledged that each of these factors alone was "quite consistent with innocent travel" but concluded that "taken together they amount to reasonable suspicion." ${ }^{32}$ The Sokolow Court noted that the DEA officers' suspicion often derives from first identifying the individual as fitting a "drug courier profile"-which

49449 US 411, 417 (1981).

49 Id at 418-22.

so See id at 419 (finding it "imperative" to recognize that "when used by trained law enforcement officers, objective facts, meaningless to the untrained, can be combined with permissible deductions from such facts to form a legitimate basis for suspicion of a particular person and for action on that suspicion").

${ }_{51} 490$ US 1, 4, 8-9 (1989). The Court also noted in its statement of the facts that Sokolow was "dressed in a black jumpsuit and wore gold jewelry." Id at 4.

62 Id at 9. 
usually comprises a set of wholly innocent characteristics that the DEA considers typical of drug traffickers. ${ }^{53}$

The Supreme Court has also expansively defined the nature of intrusion permissible under Terry. In Florida $v$ Royer, for example, the Court concluded that the "scope of the intrusion permitted [under Terry] will vary to some extent with the particular facts and circumstances of each case," though the officer must use the "least intrusive means reasonably available to verify or dispel the officer's suspicion in a short period of time. ${ }^{\$ 54}$

In the drug-trafficking context, the Supreme Court has held that, under Terry, an officer may temporarily seize not only the person but also the person's luggage, and subject it to a "canine sniff" for illegal drugs. In United States $v$ Place, DEA officers, who had reasonable suspicion to Terry stop the defendant, seized his luggage at LaGuardia Airport and then transported it to Kennedy Airport where it was subjected to a "canine sniff" test for narcotics. ${ }^{55}$ During the ninety-minute detention of the luggage, the police dog reacted positively to one of the suitcases, thus providing the officers with probable cause to obtain a search warrant for the suitcase. Upon opening the suitcase, the officers discovered cocaine. The defendant claimed that the warrantless seizure of his luggage violated his Fourth Amendment rights. ${ }^{56}$

The Supreme Court held that the principles of Terry would permit the officers to seize the luggage briefly if they had a reasonable suspicion that the luggage contained narcotics. ${ }^{57}$ The

53 Id at 10. According to Sokolow, "[s]ince 1974, the DEA has trained narcotics officers to identify drug smugglers on the basis of the sort of circumstantial evidence at issue here." Id at 10 n 6. The Supreme Court has upheld Terry stops in other cases involving the use of drug courier profiles. See, for example, Florida $v$ Royer, 460 US 491, 493 n 2 (1983). In Royer:

the detectives [sic] attention was attracted by the following facts which were considered to be within the profile: (a) Royer was carrying American Tourister luggage, which appeared to be heavy, (b) he was young, apparently between 25-35, (c) he was casually dressed, (d) he appeared pale and nervous, looking around at other people, (e) he paid for his ticket in cash with a large number of bills, and ( $f$ ) rather than completing the airline identification tag to be attached to checked baggage, which had space for a name, address, and telephone number, he wrote only a name and the destination.

Id.

54 460 US 491,500 (1983).

462 US 696, 699 (1983).

56 Id.

57 Id at 706 ("[W]hen an officer's observations lead him reasonably to believe that a traveler is carrying luggage that contains narcotics, the principles of Terry and its progeny would permit the officer to detain the luggage briefly to investigate the circumstances 
Court further held that subjecting the bags to a canine sniff test to investigate whether the suitcases contained drugs did not constitute a "search" within the meaning of the Fourth Amendment. ${ }^{58}$ Although the Place Court held that brief detentions of luggage are permissible under Terry, the Court found that the ninety-minute detention of the luggage "went beyond the narrow authority possessed by police to detain briefly luggage reasonably suspected to contain narcotics" and affirmed the lower court's judgment to suppress the incriminating evidence. ${ }^{59}$

During a Terry stop or search, the Court has allowed the seizure of any illegal contraband in "plain view" or "plain feel." In Michigan $v$ Long, the Court used the plain view doctrine, holding that: "If, while conducting a legitimate Terry search of the interior of the automobile, the officer should ... discover contraband other than weapons, he clearly cannot be required to ignore the contraband, and the Fourth Amendment does not require its suppression in such circumstances. ${ }^{\text {}} 0$ The officers searching the defendant's car for weapons during a Terry stop found an open pouch of marijuana protruding from under the armrest of the front seat-in plain view. ${ }^{61}$

In Minnesota $v$ Dickerson, the Supreme Court stated that officers could seize not only what was in plain view during a Terry stop or search, but also what was within "plain feel." The Court stated that although a Terry search must be limited to that which is necessary to discover weapons that might be used to harm the officer or others nearby, the officers "may seize nonthreatening contraband detected during a protective patdown search of the sort permitted by Terry. ${ }^{363}$

that aroused his suspicion, provided that the investigative detention is properly limited in scope.").

ss Id at 707.

59 Id at 710 .

60463 US 1032, 1050 (1983). See also United States v Hensley, 469 US 221, 235 (1985) (police are "entitled to seize evidence revealed in plain view in the course of [a] lawful stop").

61 Long, 463 US at 1036.

62113 S Ct 2130, 2136-37 (1993).

${ }^{\infty}$ Id at 2136. The Court held that the plain view doctrine had "an obvious application by analogy" to cases where an officer discovers contraband, if its incriminating character is immediately apparent, through the sense of touch during a Terry search. The Dickerson Court further stipulated that "[r]egardless of whether the officer detects the contraband by sight or by touch, however, the Fourth Amendment's requirement that the officer have probable cause to believe that the item is contraband before seizing it ensures against excessively speculative seizures." Id at 2137. 
In applying Terry, the Court has attempted to monitor the intrusiveness of a search and the basis for the search. At the same time, the Court has interpreted Terry in a way that gives police officers more discretion than Terry necessarily authorizes. First, the "totality of the circumstances" must justify reasonable suspicion, but reasonable suspicion can be generated from a set of innocent characteristics. Second, a Terry search, which was confined to a frisk in Terry, has been extended to include a canine sniff of luggage. Third, officers are permitted to seize any illegal contraband in "plain view" or "plain feel" during a Terry stop or search.

\section{Refusal to Consent as Part of the Basis FOR A TERRY STOP}

Although the Supreme Court has interpreted Terry broadly in some cases, the Court has stated repeatedly that a Terry stop or search is unlawful where a person's refusal to consent to a police request is the sole basis for the reasonable suspicion. ${ }^{64}$ As noted earlier, the Bostick Court distinguished a "noncoercive" police encounter from a seizure based on whether an individual felt free to ignore the police officers or otherwise terminate the encounter. ${ }^{65}$ An individual in a noncoercive situation would feel such freedom, the Court noted, because "[w]e have consistently held that a refusal to cooperate, without more, does not furnish the minimal level of objective justification needed for a detention or seizure." ${ }^{n 6}$

The Supreme Court has not yet addressed, however, the equally compelling question of whether a person's refusal to consent to a search request during a noncoercive police encounter can constitute even a part of the basis for a Terry stop or search, ${ }^{67}$ and lower courts are in disagreement concerning this

64 See Bostick, 501 US at 437; Royer, 460 US at 498 .

501 US at 437.

65 Id (emphasis added).

67 It could be argued that the Bostick "without more" language suggests that an individual's refusal to consent to a search request during a noncoercive police encounter can be used as part of the basis for a Terry stop. This interpretation, however, does not comport with the rest of the paragraph from the Amicus Curiae Brief for the United States that the Bostick Court cites favorably throughout its opinion. The paragraph of the Brief in which the quotation is located, instead, supports banning the use of an individual's refusal to consent to a search request during a noncoercive police encounter as part of the basis for a Terry stop. The relevant section of the Brief states: 
issue. One circuit permits police officers to use the defendant's refusal to consent to a search request as one of the factors constituting the "totality of the circumstances," while other circuits do not.

A. Cases Allowing a Refusal of a Police Request to Constitute Part of the "Totality of the Circumstances"

The Seventh Circuit, in United States $v$ Withers, has permitted the use of an individual's refusal to consent to a police request during a noncoercive police encounter to form part of the basis for a Terry stop. ${ }^{68}$ The court held that the Drug Enforcement Interdiction Task Force officers had "reasonable suspicion" to Terry stop Withers based on the following facts:

Withers arrived on a flight from Miami, a city known as a source for drugs; Withers exhibited nervous behaviors (pacing, foot tapping, nervous chain smoking, trembling, and loss of color in her face); discrepancies regarding where Withers was staying while in Florida arose in her conversation with the officers; Withers' consent to a search of her purse, but refusal to consent to search of the garment bag; and Withers' admission that she had a previous narcotics trafficking arrest. ${ }^{69}$

The Withers Court did not explain its decision to allow the refusal to search the garment bag to be considered. The court simply included it in the list of factors justifying the DEA officers' Terry stop of Withers. ${ }^{70}$

In an earlier case, United States $v$ Sterling, the Seventh Circuit noted that a refusal to consent to a police request could not be the "single additional event that ripens [the officers'] preexisting concerns to the 'founded suspicion' that a Terry stop requires." ${ }^{31}$ Although the Withers court did not explicitly adopt

Moreover, it is clear that law enforcement officers may draw no inference justifying a search or seizure from a refusal to cooperate. That is, officers lacking legal justification to detain a person may not bootstrap noncompliance into justification for a detention, because in that event a citizen would in effect have no way of declining to participate in a 'consensual' encounter with the police.

Brief for the United States as Amicus Curiae Supporting Petitioner at 25, Bostick, 501 US 429 (emphasis added).

63 972 F2d 837, 842-43 (7th Cir 1992).

Id at 843.

70 Id.

7909 F2d 1078, 1082 (7th Cir 1990). 
Sterling's "single additional event" caveat, it also did not overrule it. Because the Withers court failed to discuss its decision to include a refusal to consent in the "totality of the circumstances," it is unclear whether it considered the language in Sterling and determined that the refusal could be a factor because it was not the "single additional event" that ripened the officers concerns into reasonable suspicion, or simply did not appreciate the significance of its action. Both Sterling and Withers indicate that the Seventh Circuit allows a refusal to constitute part of the basis for a Terry stop.

B. Cases Not Allowing a Refusal of a Police Request to Constitute Part of the "Totality of the Circumstances"

The majority of circuits that have addressed this issue have held that refusal to consent to a search cannot be used as even part of a basis for a Terry stop. These courts have based their decisions on a desire to preserve the Fourth Amendment's protection against harassing police behavior and to give meaning to the Fourth Amendment's right to refuse to consent.

The Eighth Circuit in United States $v$ White suggested that a person's refusal to consent to a search request could not form a part of the basis for a Terry stop. ${ }^{72}$ In this case, DEA officers approached White in an encounter that escalated into a Terry stop, seized White's luggage, and after a canine identification of an illegal substance, obtained an arrest warrant to search the luggage, which contained cocaine. ${ }^{73}$ During the initial encounter, the officers requested permission to search White's luggage, but White "declined to give his consent." White's drug courier profile characteristics included:

that White was traveling from a source city, that he arrived early in the morning, that the flight he was on had previously yielded arrests or narcotics traffickers, and that he had purchased a one-way ticket with cash. The other behavioral factors ... were that White held his carry-on bag closely with both hands rather than using the shoulder strap, and that he appeared nervous as he walked through the airport ("repeatedly stopping and looking around") and as he talked with the officers ("[h]is hands were trembling such that he

\footnotetext{
72890 F2d 1413, 1413 (8th Cir 1989).

${ }^{73}$ Id at $1415-16$.

74 Id at 1415.
} 
had trouble removing his driver's license from his wallet"). ${ }^{75}$

The court held that the DEA officers "lacked a reasonable, articulable suspicion to justify the detention of White or his luggage, ${ }^{\prime \prime 6}$ and that specifically, the officers improperly relied on White's failure to consent as part of their justification for stopping him. ${ }^{77}$ The court cited Florida $v$ Royer, where the Supreme Court stated that "a refusal . . . does not, without more" furnish the necessary basis for a stop. ${ }^{78}$ The court's reliance on Royer-without further discussion of the issue-is unsatisfying because Royer never addressed the question of whether a refusal with other factors could be considered.

In United States $v$ Wilson, ${ }^{79}$ the Fourth Circuit suggested that refusal to consent could not be used as even a partial basis for a Terry stop. In Wilson, the defendant denied he had come off the New York shuttle and glanced behind him a few times, but he produced an identification card and agreed to a search of his person and luggage when asked. ${ }^{80}$ Police officers repeatedly asked Wilson to consent to a search of his coats, which Wilson consistently refused to do. Eventually, Wilson consented to a search, which revealed a brown paper bag containing cocaine. The court held that the officers' continual requests to search the coats after Wilson's repeated denials converted the encounter into a Terry stop. The Court suppressed the evidence that the search revealed because the evidence was the product of a stop for which the officers lacked reasonable suspicion. Although the court stated that it was "not prepared . . . to rule that the form of a denial can never be included as a factor to be considered in determining whether an investigative stop was justified," it concluded that Wilson's refusal could not be considered. The court said it was "wary" of allowing police to use an individual's right to refuse to consent to justify reasonable suspicion. ${ }^{81}$ The court reasoned

75 Id at 1417, quoting Magistrate's Memorandum and Recommendations at 7, No 880104-CR(1) (July 13, 1988).

76 Id at 1419. Although the White court asserted that the original seizure "violated" the Fourth Amendment, the court affirmed the district court's denial of White's motion to suppress. The court maintained that "the facts of this case are close enough to the line of validity to make the officers' belief in the validity of the warrant objectively reasonable." Id.

7 Id at 1417 n 4, citing Royer, 460 US at 498.

78 Royer, 460 US at 498.

79953 F2d 116 (4th Cir 1991).

80 Id at 126.

si Id. 
that a contrary holding in that case would result in the diminishment of the Fourth Amendment's role as "the bulwark against 'overbearing or harassing' police conduet.."82 The court warned that to hold otherwise might give police license to persist in their requests for consent until reasonable suspicion did in fact arise. $^{83}$

The D.C. Circuit, in United States $v$ Carter ${ }^{84}$ stated in dicta that an officer could not use a person's withdrawal of consent during a consensual search as part of the basis for reasonable suspicion. In Carter, a plainclothes detective approached Carter during a brief stopover on an Amtrak train at Union Station. Carter first agreed to let the detective search his tote bag. When the detective found a lunch bag inside, Carter snatched the lunch bag from the detective, then offered to show the officer that the lunch bag contained food. Carter "put his hand inside the paper bag, felt around, and finally withdrew his hand-which was empty.... The detective stated, 'I take it you don't want me to search that?' and Carter replied, 'That's right." ${ }^{\prime 85}$ At this point, the detective seized Carter's lunch bag for a canine sniff, which revealed that the bag contained seventy-nine ziplock bags of crack cocaine. ${ }^{86}$

In dicta, the court stated that refusal to consent to a search could not be used as part of the basis for reasonable suspicion. However, by refusing to characterize Carter's behavior as either a refusal or a withdrawal of consent to the officer's search request, the court avoided having to follow the implications of its own suggestion. The court noted that "[t]he constitutional right to withdraw one's consent to a search would be of little value if the very fact of choosing to exercise that right could serve as any part of the basis for finding [ ] reasonable suspicion." ${ }^{\$ 87}$ The court concluded on the facts before it, however, that this was immaterial. Instead, the court considered Carter's "offer to show the food in the paper bag, followed by his removing his empty hand from the bag" as part of the "totality of the circumstances. ${ }^{\text {" }} 8$ Carter's "empty-handed" offer, the court reasoned, was behavior outside of Carter's withdrawal of consent-which had occurred previously

\footnotetext{
82 Id, quoting Terry, 392 US at 15.

83953 F2d at 126.

84 985 F2d 1095 (1993).

\&5 Id at 1096.

86 Id.

87 Id at 1097 (citations omitted) (emphasis added).

\&s Id.
} 
when Carter retook the bag-and therefore did not constitute a refusal to consent to a search. ${ }^{89}$

Not surprisingly, the dissent in Carter argued that the court misconstrued the facts in a way that was unfair to the defendant. ${ }^{90}$ The Carter court, the dissent noted, condemned the use of withdrawal of consent to a search request as part of the basis for reasonable suspicion, but then-by allowing reasonable suspicion to turn on the "manner" in which consent is withdrawn-went on to do exactly what it had proscribed. The dissent suggested that "[p]ermitting the police to rely on the atmospherics of the refusal or withdrawal of consent to supply the reasonable suspicion ... strips the legal right of withdrawal of all practical value."11 The majority had effectively "eviscerate[d] the right to withdraw consent (certainly midway through a previously consented-to search) to nothing more than a pious throwaway sentence in judicial opinions approving searches. ${ }^{.92}$

\section{Prohibiting the USE OF a Refusal to Consent to a} POLICE REQUEST AS SUPPORT FOR A TERRY STOP

A refusal to consent to a search request should not be part of the basis for a Terry stop for four main reasons. First, the use of a refusal contaminates the voluntariness of a truly consensual search. Second, it effectively turns noncoercive police encounters into seizures. Third, it undermines the purpose of the Fourth Amendment by giving police officers a tool with considerable potential for abuse. Fourth, allowing the courts to find reasonable suspicion based on a failure to consent grants them too much discretion. Under the "totality of the circumstances" test, courts would be able to accord the refusal the weight needed to arrive at the outcome they desire. This is particularly dangerous because courts have already considerably narrowed the traditional protections of the Fourth Amendment.

\section{A. Consent}

If courts are permitted to use refusal to consent as any part of the basis for reasonable suspicion, even truly consensual searches will be tainted by an element of involuntariness because

89 Id at $1097 \& \mathrm{n} *$.

${ }^{90}$ See id at 1098 (Wald dissenting).

91 Id at 1100.

92 Id. 
people will not feel completely free to withhold their consent. In evaluating whether an alleged consensual search is in fact voluntary, the Supreme Court considers that the "Fourth and the Fourteenth Amendments require that a consent not be coerced, by explicit or implicit means, by implied threat or covert force." ${ }^{\text {"93 }}$ Consent, to be voluntary, must be "uncontaminated by any duress or coercion." ${ }^{24}$ Where an individual's refusal to consent to a request can constitute a part of the basis for a Terry stop, a reasonable person's decision to consent is not uncontaminated by any duress or coercion. The fact that a refusal to consent can be used against an individual is a coercive factor that operates to contaminate the voluntariness of the consent. ${ }^{95}$

Moreover, the Supreme Court has already recognized a right to refuse consent. It has stated that "knowledge of a right to refuse [consent]" must be considered in evaluating the voluntariness of a consent..$^{96}$ This "right" to refuse is undermined, however, if the exercise of that right can be used against a person. In a discussion of the Fifth Amendment, the Court recognized this notion: "[A] penalty imposed by courts for exercising a constitutional privilege ... cuts down on the privilege by making its

${ }^{93}$ Schneckloth $v$ Bustamonte, 412 US 218, 228 (1973).

94 Simmons v Bomar, 349 F2d 365, 366 (6th Cir 1965) (emphasis added).

95 Individuals who decline an officer's request additionally confront the threat of "various informal and extra-legal means available [to police officers] for situations where their authority is questioned." Tracey Maclin, Justice Thurgood Marshall: Taking the Fourth Amendment Seriously, 77 Cornell L Rev 723, 810-11 (1992). Maclin explains:

Officers, for example, may decide to "teach a lesson" to an uncooperative person. Because of the violent nature of these "lessons" and the resulting denigration of the individual, the Court misses the mark when it speculates that a person considering refusal may do so "without fearing prosecution." In the forefront of a person's mind is the fear that a lack of cooperation may cause the police to arrest him, to approach him again later in the trip, or even worse, to respond violently and physically.

Id (citations omitted). See also Bostick, 501 US at 447 (Marshall dissenting) ("But in light of the intimidating show of authority that the officers made upon boarding the bus, respondent reasonably could have believed that such behavior would only arouse the officers' suspicions and intensify their interrogation. Indeed, officers who carry out bus sweeps like the one at issue here frequently admit that this is the effect of a passenger's refusal to cooperate."). Further proof that individuals feel coerced when asked for permission to search is the fact that in one study, "[o]ut of the approximately 300 persons subjected to a field stop, not one declined to answer the police officer's question." Note, $77 \mathrm{Va}$ $\mathrm{L}$ Rev at 202 (cited in note 25) (citation omitted). That individuals already feel coercion upon a police encounter further supports having a rule that unambiguously permits an individual to refuse to consent without any adverse legal ramifications.

${ }_{96}$ See Schneckloth, 412 US at 234, 249 (emphasis added). See also Evelyn Aswad, et al, Warrantless Searches and Seizures, 82 Georgetown L J 622, 659 (1994) ('The factors used to determine whether express consent is voluntary include: the individual's knowledge of her constitutional right to refuse consent ....) (emphasis added). 
assertion costly." ${ }^{\prime \prime 7}$ The nature of a right is that its exercise is protected from harmful legal consequences. Such harmful legal consequences are present whether the refusal to consent is used against an individual as the sole factor or as one of many factors contributing to a Terry stop or search..$^{98}$ As the dissent in Carter noted, permitting police to rely on a refusal as part of the basis for an otherwise unconstitutional search makes the legal right to refuse consent valueless. ${ }^{99}$

\section{B. Seizures}

The Bostick reasoning, which prohibited the use of refusal to consent as the sole basis for a seizure, supports prohibiting the use of a refusal to consent as part of the basis for a Terry stop or search. According to Bostick, an individual has been seized where a reasonable "innocent person" would not feel "free to decline the officers' requests or otherwise terminate the encounter." ${ }^{\prime 100}$ If an individual does not feel free to decline a search request, the notion of a "consensual" search becomes meaningless. Any apparently consensual search, therefore, would actually be a seizure.

The "feel free to decline the officers' request" test is valid, the Court notes, because a refusal to consent cannot be the sole basis for a seizure. ${ }^{101}$ The Court implies that where an individual's refusal to consent to a search request could constitute the sole basis for a search, all police encounters would, in reality, be seizures. This would be so because people would know that their refusal could be used against them.

Similarly, the use of an individual's refusal to consent as even a part of the basis for a search would turn all police encounters into seizures. It is simply impossible to view the decision to refuse to consent as having the requisite freedom, or "absence of

${ }^{97}$ Griffin $v$ California, 380 US 609, 614 (1965) (holding that the Fifth Amendment forbids both comment by prosecution on an accused's refusal to testify and instructions by the court that such refusal is evidence of guilt).

98 See Alan Brownstein, How Rights are Infringed: The Role of Undue Burden Analysis in Constitutional Doctrine, 45 Hastings L J 867, 930 (1994) ("Even a one-dollar burden on the exercise of a right can violate constitutional guarantees."); Note, "Unconscionable" Conditions: A Contractual Analysis of Conditions on Public Assistance Benefits, 94 Colum L Rev 193, 207 (1994), citing Memorial Hospital v Maricopa County, 415 US 250, 253-54 (1974) ("The clear implication was that the 'deterrence' of the exercise of a right and a penalty on that right were separate things and that either of these effects sufficed to make out an unconstitutional condition.").

99 See Carter, 985 F2d at 1100 (Wald dissenting).

100 Bostick, 501 US at 438-39.

101 Id at 437 . 
restraint,"102 when that refusal can be used against the individual in any manner, no matter how slight. The refusal may be all the officer needs to find reasonable suspicion. Thus, either to withhold or to give consent would result in a search. Because individuals cannot know whether their refusal will be the tipping factor, individuals cannot feel unrestrained when police officers request permission to search. In all police encounters, a person's freedom will be limited and, therefore, all encounters should be considered seizures under the Bostick Court's reasoning. The only difference is one of degree, but a limitation on a person's freedom should not be accepted simply because it is a lesser intrusion.

The inherently coercive nature of any kind of police encounter further militates against allowing refusal to consent as a partial basis for reasonable suspicion. Some commentators have criticized the Bostick "feel free" test as not recognizing that a "reasonable person does not feel free to walk away from an officer in any police-citizen encounter." ${ }^{\text {"103 }}$ In fact, individuals questioned by police rarely refuse to comply, often because they fear police harassment. ${ }^{104}$ If this is true, then it is even more important that the law not further limit an individual's freedom by permitting the refusal to consent to support a Terry stop or search.

\section{Police Discretion}

The purpose of the Fourth Amendment is to check police discretion and power and "to prevent arbitrary and oppressive interference by enforcement officials with the privacy and personal security of individuals." ${ }^{105}$ Permitting the police to use an individual's refusal to consent to a search request as part of the basis for a Terry stop or search grants the police very broad discretion. Merely by approaching an individual, officers who lack enough suspicion to Terry stop and search on the spot can

\footnotetext{
102 Black's Law Dictionary 664 (6th ed 1990) (defining "freedom").

${ }^{103}$ Note, Florida v. Bostick: The Fourth Amendment-Another Casualty of the War on Drugs, 1992 Utah L Rev 601, 642 (emphasis added).

${ }_{104}$ That reasonable people do not feel free to decline an officer's requests is substantiated by the fact that "in the real world, individuals questioned by police rarely, if ever, disregard an officer's request." Id. Another scholar, claiming the "no seizure notion is unadulterated sophistry," explained that "[a]nyone with a lick of sense" does not believe that he is free to refuse a police officer's requests or walk away because he knows that "these things will only aggravate the situation and cause him more trouble." Gerald G. Ashdown, Drugs, Ideology, and the Deconstitutionalization of Criminal Procedure, $95 \mathrm{~W}$ Va L Rev 1, 22 (1992).

${ }_{105}$ United States v Martinez-Fuerte, 428 US 543, 554 (1976).
} 
strengthen their claim of reasonable suspicion. If the individual does not refuse at first, officers can persist in questioning the individual until the individual refuses to consent. ${ }^{106}$

The factor at issue - the refusal to consent to a search or other police request-differs from other kinds of factors considered in a "totality of the circumstances" test in one crucial respect: it is or can be generated by the police themselves. Unlike characteristics or behaviors of an individual, such as nervousness, backward glances, or tickets paid with cash, the refusal to consent occurs only when individuals are selected by the police for questioning. Thus, this factor is particularly susceptible to police abuse.

Our country's history of arguably racist police practices cautions against a rule that allows the police to strengthen a claim against those whom they choose arbitrarily. ${ }^{107}$ Those most harmed by this unbridled police discretion and the courts' inability to monitor this discretion are likely to be blacks and other minorities. ${ }^{108}$ It is well documented that blacks are far more likely to be arrested for drug law violations than whites. ${ }^{109}$ The Terry Court itself recognized that "minority groups, particularly Negroes, frequently complain" about the "wholesale harassment by certain elements of the police community."110 Justice Mar-

16 The Wilson court recognized the "temptation" for police officers to "manufacture justification for prolonged investigative stops" in the hopes of procuring a refusal. Wilson, 953 F2d at 127. The Wilson court also cautioned that officers are invited "to disregard a suspect's attempts to ignore further questioning and to persist until 'reasonable suspicion' [is] created ...." Id at 126.

107 See Carol S. Steiker, Second Thoughts About First Principles, 107 Harv L Rev 820, 855 (1994) ("Given the history of racial discrimination in law enforcement, concern about the 'arbitrariness or bias' of the police as decisionmakers is certainly warranted."). As one commenter explained:

Put in the simplest terms, the criminal justice system treats African Americans and Hispanic Americans differently than it does whites. This disparate treatment reaches beyond the end product of the system, that is, the fact that African Americans are vastly overrepresented in prisons and jails relative to their numbers in the general population. Rather, these inequities reach down to the first level of the criminal justice process, the points at which police decide who they will investigate, approach, stop, frisk, and ultimately arrest.

David A. Harris, Factors for Reasonable Suspicion: When Black and Poor Means Stopped and Frisked, 69 Ind L J 659, 679 (1994) (citations omitted).

168 See Harris, 69 Ind $L J$ at 677 (citation omitted) ("The unfortunate fact is that Terry and its progeny have resulted in stops and frisks of residents of inner cities-primarily poor persons, African Americans, and Hispanic American-far out of proportion to their numbers, and often without justification.").

169 See note 8.

110 Terry, 392 US at 14. 
shall posited that officers conducting suspicionless searches choose their subjects based more on the "unspeakable" than on the "inarticulable."111 Explaining that some officers admit that their decision to select people in suspicionless sweeps is often based on race, Marshall wrote:

It does not follow ... that the approach of passengers during a sweep is completely random. Indeed, at least one officer who routinely confronts interstate travelers candidly admitted that race is a factor influencing his decision whom to approach. ${ }^{112}$

\section{The "Totality of the Circumstances" Tèst}

Permitting police officers to use the refusal to consent as part of the basis for a Terry stop gives the police a powerful tool because the courts appear to give a refusal, when included, considerable weight. Cases with similar factors under the "totality of the circumstances" test come out differently depending on whether the court decides that a refusal to consent can contribute to the "totality of the circumstances." In Wilson, for example, the court did not permit the use of the defendant's refusal, and did not find reasonable suspicion where these were the factors considered: Wilson arrived from a source city, exhibited nervous behaviors, and denied coming off the New York shuttle. ${ }^{113}$ In Withers, by contrast, where the court permitted the use of the defendant's refusal to consent as part of the basis for the Terry stop, the court found reasonable suspicion based on similar factors: Withers arrived from a city known as a source for drugs, exhibited nervous behaviors, admitted that she had a previous narcotics trafficking arrest, and told an inconsistent story of where she was staying while in Florida. ${ }^{114}$ Although this is only one example, it is striking enough to suggest that, without a rule prohibiting the use of a refusal to consent as part of the basis for

111 Bostick, 501 US at 441-42 n 1 (Marshall dissenting).

112 Id (emphasis added). See also United States v Jennings, 1993 US App LEXIS 926, *13-14 (6th Cir) (unpublished memorandum), citing Bostick, 501 US at 441-42 n I (Marshall dissenting) (where an officer stops a disproportionate number of black travelers in airports, the officer's "reasons for stopping these individuals is less likely to be inarticulable than unspeakable"); United States $v$ Taylor, 956 F2d 572, 581 a 1 (6th Cir 1992) (Keith dissenting) ("One of the officers admitted at the evidentiary hearing that at least seventy-five percent of those followed and questioned in these consensual police stops are black.").

${ }_{133}$ See Wilson, 953 F2d at 120, 126.

11 See Withers, 972 F2d at 843. 
a Terry stop, the vagueness of the "totality of the circumstances" test may give courts the discretion to weigh the factors so as to arrive at any outcome they desire. ${ }^{115}$

This is particularly disturbing because in recent times the courts have been inclined toward intrusion on traditionally protected Fourth Amendment rights. People who possess drugs are unsympathetic defendants. ${ }^{116}$ When police find drugs on people they stop, courts are predisposed to rule against these defendants' Fourth Amendment claims. ${ }^{117}$ Moreover, in most Terry stop drug cases, the courts are put in the awkward position of having to exclude the incriminating evidence wherever they find that a search is unreasonable. ${ }^{118}$ Thus, where drugs are involved, courts may intrude on traditionally protected Fourth Amendment rights.

115 Under the "totality of the circumstances" test, "equality of treatment is difficult to ... achieve; predictability is destroyed; judicial arbitrariness is facilitated; judicial courage is impaired." Antonin Scalia, The Rule of Law as a Law of Rules, 56 U Chi I Rev 1175,1182 (1989). At least one commentator has criticized the use of discretionary standards in Fourth Amendment jurisprudence:

Rules ... both guide courts in their ex post adjudication of Fourth Amendment rights and constrain police in their ex ante decisions about when and whether to search and seize. Generally, rules are often preferred over standards because they "reduce the danger of official arbitrariness or bias" and thus "embody a distrust for the decisionmaker they seek to constrain."

Steiker, 107 Harv L Rev at 854 (cited in note 107).

${ }^{116}$ See Maclin, $35 \mathrm{Wm}$ \& Mary L Rev at 238 (cited in note 5) (citation omitted) ("My guess is that the Court sees the typical Fourth Amendment claimant as a second-class citizen, and sees the typical police officer as being overwhelmed with the responsibilities and duties of maintaining law and order in our crime-prone society. This dual perception may explain the Court's reluctance to subject police conduct to vigorous judicial oversight."); Steven Wisotsky, Crackdown: The Emerging Drug Exception' to the Bill of Rights, 38 Hastings L J 889, 907 (1987) ("[T]he War on Drugs steamroller has flattened judicial barriers .... In case after case, the courts have whittled away vital protections for the accused. This process has reached its apogee in the realm of search and seizure.) (emphasis added); Comment, Florida v. Bostick: The Fourth Amendment Takes a Back Seat to the Drug War, 27 New Eng L Rev 825, 826-27 (1993) ("The Bostick decision is significant because it represents the most recent example of the Court's willingness to narrow Fourth Amendment protections in order to address a societal problem.").

117 Finkelman, $66 \mathrm{~S}$ Cal L Rev at 1398 (cited in note 5) (noting courts' tendency to rule against the accused in cases involving illegal drugs and describing the phenomenon as "the trend of law enforcement in the era of zero tolerance and the war on drugs").

118 The courts have a history of overvaluing law enforcement interests in Fourth Amendment cases. See Nadine Strossen, The Fourth Amendment in the Balance: Accurately Setting the Scales Through the Least Intrusive Alternative Analysis, 63 NYU L Rev 1173, 1176 (1988) (the Court "regularly undervalues the fourth amendment interests jeopardized by every search and seizure, while overvaluing the countervailing law enforcement interests"); Steiker, 107 Harv L Rev at 855 (cited in note 107) ("WW]e must remember that in Fourth Amendment jurisprudence, the police are the courts' special audience and the frontline of Fourth Amendment decisionmaking."). 
The Court has already intruded on traditional notions of Fourth Amendment rights by carving out the Terry stop and search as an exception to the probable cause rule and by allowing, and liberally applying, the exigent circumstances exception to the warrant requirement. ${ }^{119}$ The Court also intruded on previously protected Fourth Amendment rights when it permitted officers to Terry stop a person's luggage and to subject it to a "canine sniff" for illegal drugs, ${ }^{120}$ when it held that police can seize illegal contraband in "plain view" or "plain feel" during a Terry stop or search, ${ }^{121}$ and when it found that Terry stops and searches are permissible even if the "totality of the circumstances" is nothing more than a set of innocent behaviors. ${ }^{122}$ The Court further intruded on traditionally protected Fourth Amendment rights when it allowed Terry stops and searches where the purpose of the stop and search was not to ensure police safety. ${ }^{123}$ Given this trend, the courts are not likely to prevent police officers from abusing their discretion by eliciting a refusal in order to justify otherwise unreasonable Terry stops and searches. ${ }^{124}$

\section{CONCLUSTON}

Without a rule prohibiting the use of an individual's refusal to consent to a search request as part of the basis for a Terry stop, the integrity of the Fourth Amendment is compromised. When an individual consents to a police request, the validity of

119 See text accompanying note 40 .

120 See text accompanying notes 55-59.

${ }^{121}$ See text accompanying notes $60-63$.

${ }^{122}$ See text accompanying notes 51-53.

${ }^{123}$ For example, none of the cases discussed in Part II of this Comment mentions the officers' fear that the defendant may have possessed weapons. See also Finkelman, $66 \mathrm{~S}$ Cal L Rev at 1418 (cited in note 5) ("a reliance on Terry to justify drug searches is fundamentally wrong"). Professor Finkelman, distinguishing Terry stops in the drug trafficking context from the stop in Terry $v$ Ohio, explained: "In the war on drugs, the intrusions have become greater, and, unlike Terry, they are usually not based upon a reasonable apprehension of violence or even a search for weapons. Rather, they are to prevent people from transporting illegal drugs from one place to another." Id at 1417. Another difference between the original Terry stop and drug-trafficking Terry stops is that, although both are invasive to an individual's privacy, the DEA officers in Terry stop cases involving drugs are inconveniencing travellers, who may miss connections or important meetings. See id at 1418 .

${ }^{124}$ The problem is self-perpetuating. The courts, prone to rule in favor of the reasonableness of a Terry stop, will encourage police officers to conduct unreasonable searches, which will result in more court decisions that violate individuals' Fourth Amendment rights. 
the consent is established by its voluntariness-the fact that it is "uncontaminated by any duress or coercion." The use of a refusal to consent as support for a Terry stop creates coercion and contaminates the voluntariness of a consent. A noncoercive police encounter, as opposed to a seizure, assumes that the individual feels free to decline a police request. But if a refusal to a police request can be used against an individual, that person cannot feel free and all police encounters are effectively seizures. The purpose of the Fourth Amendment, to check police discretion, is undermined, because police officers can arbitrarily approach individuals with insufficient basis for a Terry stop and obtain sufficient grounds if the individual refuses their request. If courts are permitted to consider a refusal to consent under the vague "totality of the circumstances" test, the weight the refusal is accorded may be determined by the outcome the court desires. 


\section{-}

. 